\title{
Mulberry (Morus nigra L., Moraceae) Hosting Scale Insects Crypticerya brasiliensis (Hempel, 1900) (Hemiptera: Monophlebidae) and Pseudaulacaspis pentagona (Targioni-Tozzetti, 1886) (Hemiptera: Diaspididae) in the Federal District, Brazil
}

\author{
Marcelo T. de Castro ${ }^{1}$, Sandro C. L. Montalvão ${ }^{2}$, Ana Lúcia B. G. Peronti ${ }^{3}$, Vera R. dos S. Wolff ${ }^{4}$ \\ $\&$ Rose G. Monnerat ${ }^{2}$ \\ ${ }^{1}$ Departamento de Agronomia, Centro Universitário ICESP, Brasília, DF, Brazil \\ ${ }^{2}$ Prédio de Controle Biológico, Embrapa Recursos Genéticos e Biotecnologia, Brasília, DF, Brazil \\ 3 Faculdade de Ciências Agrárias e Veterinárias, Universidade Estadual Paulista "Júlio de Mesquita Filho“, \\ Jaboticabal, SP, Brazil \\ ${ }^{4}$ Departamento de Diagnótico e Pesquisa Agropecuária, Secretaria de Agricultura, Pecuária e Irrigação de Porto \\ Alegre, RS, Brazil \\ Correspondence: Marcelo T. de Castro, Departamento de Agronomia, Centro Universitário ICESP, QS 05 Rua \\ 300 Lote 01, 71961-540, Águas Claras, Brasília, Distrito Federal, Brazil. Tel: 55-61-981-878-161. E-mail: \\ marceloengflorestal@gmail.com
}

$\begin{array}{ll}\text { Received: February 15, } 2020 & \text { Accepted: March 18, 2020 Online Published: April 15, } 2020 \\ \text { doi:10.5539/jas.v12n5p89 } & \text { URL: https://doi.org/10.5539/jas.v12n5p89 }\end{array}$

The research is financed by "Núcleo Interdisciplinar de Pesquisa (NIP), Centro Universitário ICESP".

\begin{abstract}
The black mulberry tree (Morus nigra L. Moraceae), a perennial shrub, is one of the most abundant species in the urban afforestation of Brasília, Federal District, Brazil. This work records the first occurrence of Crypticerya brasiliensis (Hempel, 1900) (Hemiptera: Monophlebidae) and Pseudaulacaspis pentagona (Targioni-Tozzetti, 1886) (Hemiptera: Diaspididae) infesting M. nigra in the Federal District, Brazil. For this study, 20 specimens of M. nigra trees were inspected during September to October 2019, in two locations of the Federal District, Brazil, and the presence of scale insects were found on the trunks, stems, and leaves. The main damage caused by $C$. brasiliensis in the sampled trees were dry stems and branches along with yellow leaves, by the insects feeding mainly on the leaf veins. Pseudaulacapis pentagona was observed on the branches and stems of the plant isolated from the second sampling point. Infested branches were dry and leafless, with many scale insects, and some branches displayed small cracks. This is the first time M. nigra has been registered as a host plant of $C$. brasiliensis, as well as first occurrence of P. pentagona infesting M. nigra in the Federal District, Brazil.
\end{abstract}

Keywords: phytophagous insect, agricultural entomology, damage in trees, scale insects

\section{Introduction}

The urban afforestation of Brasília, Federal District, Brazil, includes hundreds of trees that range from exotic to native species. Among these species, the black mulberry tree (Morus nigra L., Moraceae) is one of the most abundant and can be found in various parts of the city (Silva Júnior \& Lima, 2010). Mulberry plants are grown on virtually every single continent and are highly adapted to various environmental and soil conditions (Ercisli \& Orhan, 2007).

Its sweet fruit, and ornamental beauty, and abundant shade make M. nigra an appreciated perennial shrub (Silva Júnior \& Lima, 2010; Okamoto et al., 2013). Its cultivation had begun in several Asian countries as its leaves can be used as food for rearing silkworms (Weiguo et al., 2005). In addition, studies indicate that its fruits and leaves have medicinal properties (Padilha et al., 2010; Oliveira et al., 2018).

From the insects associated to mulberry, several scale insects have been described, including representatives of the families Coccidae (7), Diaspididae (5), Pseudococcidae (5), and Lecanodiaspididae (1) (Garcia Morales et al., 
2016). Gallo et al. (2002) mention that the main mulberry pests are the scale insect Pseudaulacaspis pentagona (Targioni-Tozzetti, 1886) (Hemiptera: Diaspididae), caterpillars of Automeris memusae (Walker, 1855) (Lepidoptera: Saturniidae), and the beetles Arniticus sp. (Coleoptera: Curculionidae) and Bolax flavolineatus (Mannerheim, 1829) (Coleoptera: Scarabaeidae).

This work records the first occurrence of Crypticerya brasiliensis (Hempel, 1900) (Hemiptera: Monophlebidae) infesting $M$. nigra trees, as well as the first occurrence of P. pentagona in mulberry in the Federal District, Brazil.

\section{Method}

\subsection{Presence of Scale Insects on Mulberry}

Twenty M. nigra trees were inspected during September and October 2019, at two locations in the Federal District, Brazil, to observe the presence of scale insects on the trunks, stems, and leaves of the trees. This first sampling site was a small forest $\left(15^{\circ} 45^{\prime} 12.4^{\prime \prime} \mathrm{S} ; 4^{\circ} 53^{\prime} 36.6^{\prime \prime} \mathrm{W}\right)$ containing 19 mulberry trees. The second site $\left(15^{\circ} 56^{\prime} 55.2^{\prime \prime} \mathrm{S} ; 48^{\circ} 10^{\prime} 00.8^{\prime \prime} \mathrm{W}\right)$ was an isolated tree.

\subsection{Slide-Mounted Procediments for the Scale Insects}

The collected specimens were stored in plastic "eppendorf type" tubes in $70 \%$ ethanol. Later, the specimens were mounted on slides following the method of Gullan (1984) and were identified with a compound light microscope. Crypticerya brasiliensis was identified using the key from Kondo et al. (2016a), and P. pentagona using Ferris (1937), and Claps and Wolff (2003), both based on adult female morphology.

\subsection{Storage of Voucher Species}

Voucher specimens were deposited in the following institutions: specimens of $C$. brasiliensis in the Reference Collection of Insects and Mites (CRIA) at the Universidade Estadual Paulista, Jaboticabal, São Paulo, Brazil; and P. pentagona in the Collection of "Ramiro Gomes Costa Museum of Entomology (MRGC), State Secretariat for Agriculture, Livestock, and Rural Development, Rio Grande do Sul (DDPA, SEAPDR, RS)".

\section{Results and Discussion}

\subsection{Identification}

Two species of scale insects were found in the evaluated plants, C. brasiliensis and P. pentagona.

\subsection{Crypticerya brasiliensis}

The most abundant species was C. brasiliensis (Figure 1), with nymphs and adult females observed on the leaves, stems, and trunks of 19 plants evaluated in the first location. Due to the large amount of honeydew eliminated by this monophlebidae, the tree structures infested by these insects had a large amount of sooty mold. The main damage caused by $C$. brasiliensis in the sampled trees were dry stem and branch and yellow leaves, with individuals feeding mainly on leaf veins. One of them was completely weakened by the attack of this scale insect and was less developed than others.

The Neotropical species, C. brasiliensis, was described from specimens collected in São Paulo, SP, and has been recorded in Panama, Colombia, Guyana, Peru, and Argentina. Although it is a polyphagous species, it has few known host plants, in which most of them are shrubs and ornamental trees, such as: fishtail palm (Caryota sp., Arecaceae); camphor tree (Cinnamomum camphora Nees \& Eberm, Lauraceae); croton (Codiaeum sp., Euphorbiaceae); fig trees (Ficus sp., Moraceae), tulip tree (Liriodendron tulipifera L., Magnoliaceae); rose bush (Rosa sp., Rosaceae) (Hempel, 1912; Lizer y Trelles, 1938); and red bottlebrush flower (Callistemon viminalis (Sol. ex Gaertn.) G. Don, Myrtaceae) (García Morales et al., 2016).

This monophlebid was observed by Hempel (1900) often infesting stem and trunk of its hosts, and it has been reported to cause the dieback of numerous shade trees in São Paulo, Brazil. More recently, C. brasiliensis was recorded as causing significant damage to many types of shrubs and guava trees in the Department of Boyacá, Colombia, and in the state of São Paulo, Brazil; and on red bottlebrush flower in Goiânia, Goiás, Brazil (Kondo et al., 2016b).

\subsection{Pseudaulacaspis pentagona}

Pseudaulacaspis pentagona was observed on the branches and stems of the plant isolated from the second sampling site (Figure 2). The infested branches were dry and leafless, and some had small cracks. 

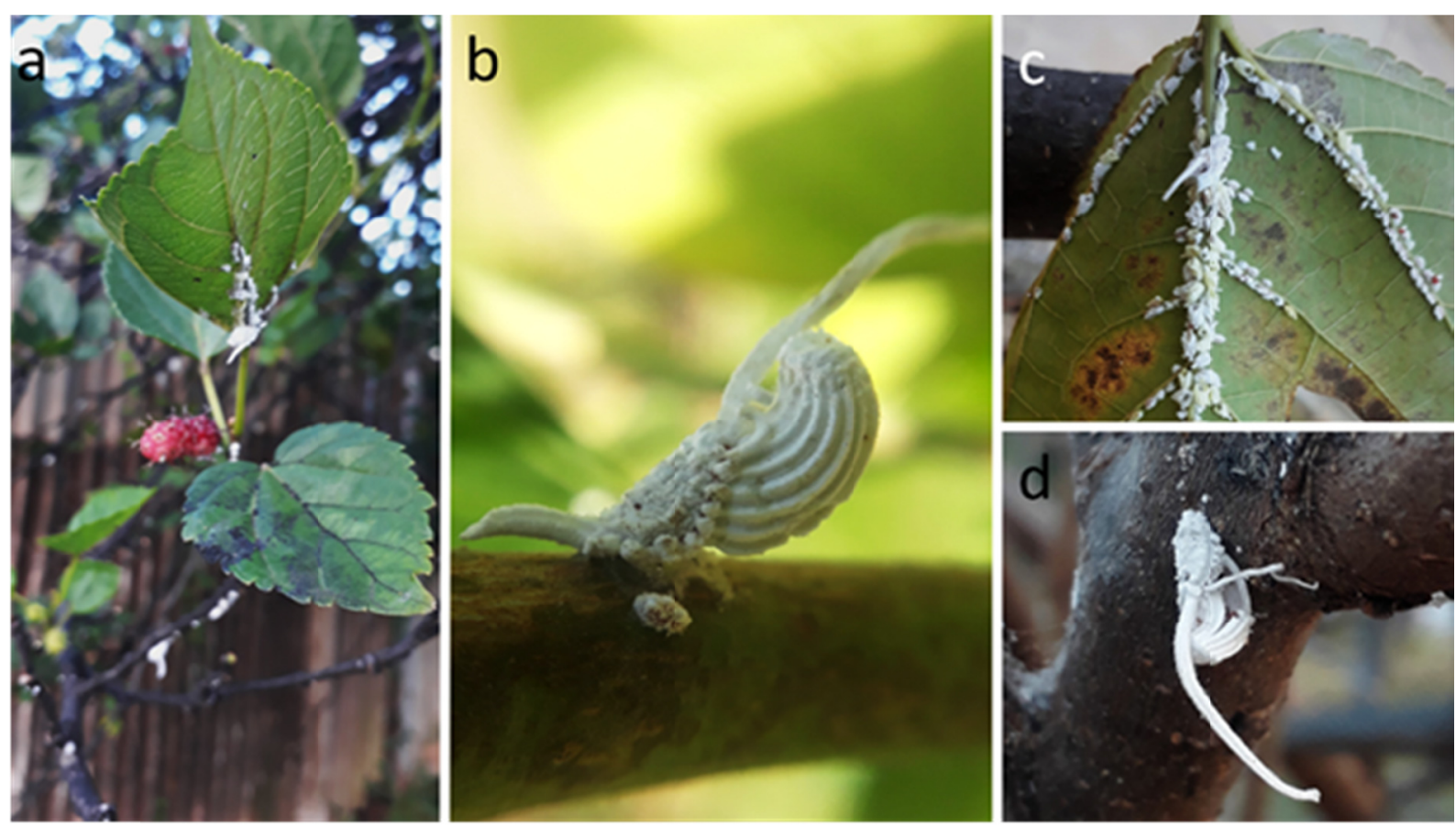

Figure 1. Crypticerya brasiliensis on M. nigra, Federal District, Brazil: (a) Infestation on the top leaf and sooty mold on inferior leaf, (b) Adult female and nymph on stem, (c) Detail of the monoflebids arranged on the veins of abaxial leaf' surface, (d) Dorsal view of adult female on trunk
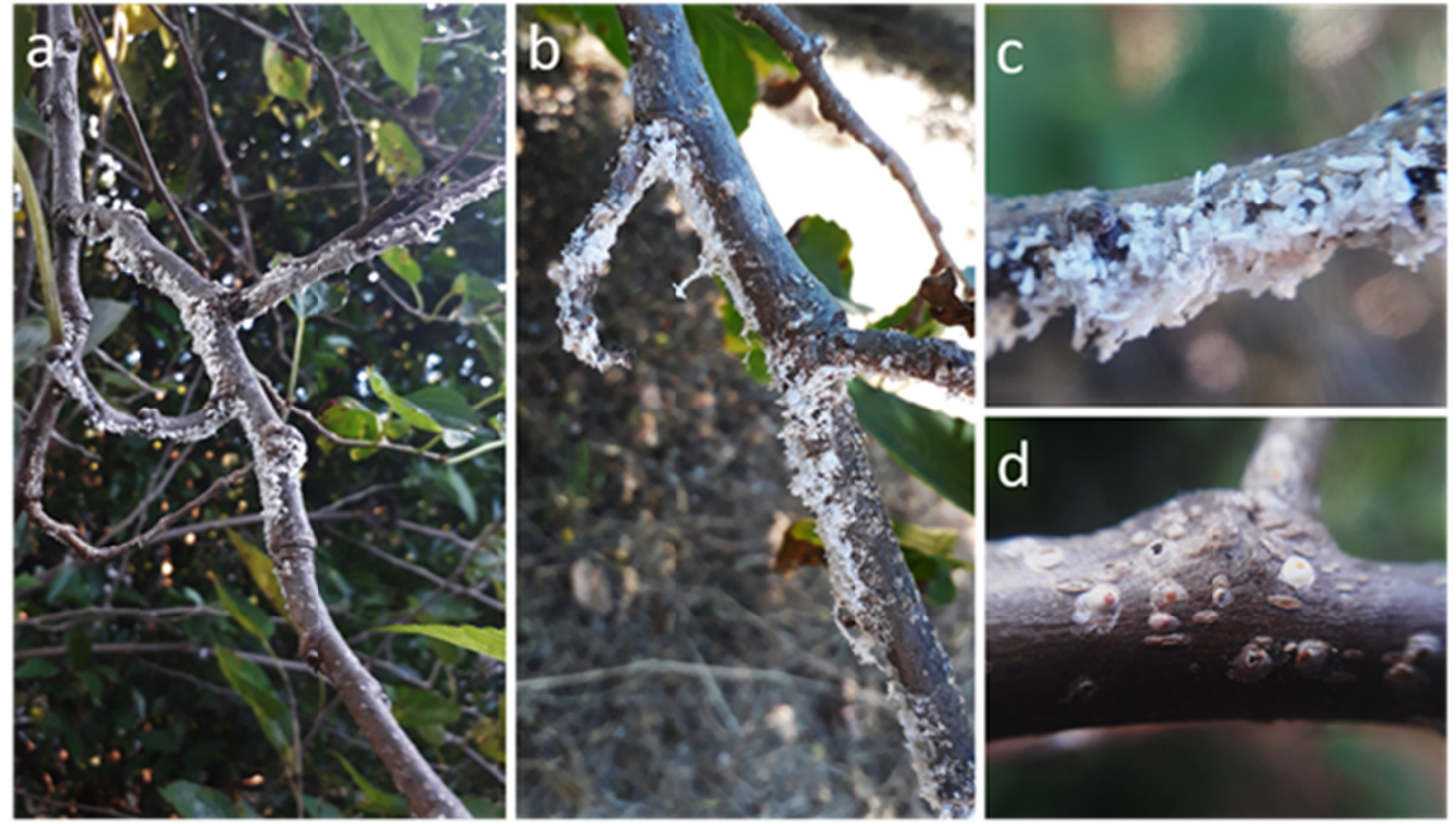

Figure 2. Pseudaulacaspis pentagona on M. nigra, Federal District, Brazil: (a), (b), (c) Armored scale insects infested branches, (d) Detail of armored scale insects on the branch

Pseudaulacaspis pentagona of Palearctic origin, is a cosmopolitan and polyphagous species, and has been registered in 110 countries on host plants of 221 genera in 85 families (Garcia Morales et al., 2016). Exotic in South America, this diaspidid was first recorded on this continent in 1902 and is now widespread (Wyckhuys et 
al., 2013). This diaspidid can be a major pest in many crops, including fruit and ornamental plants (Watson, 2002), and is listed by Miller and Davidson (1990) as a serious and widespread pest around the world.

This diaspidid is widely distributed in Brazil, in 10 states from North to the South region of the country, totaling a list of 30 host plants for these states. However, P. pentagona had not been recorded in the Federal District or in the state of Goiás (Silva et al., 1968; Claps et al., 2001). The most recent records of host plants includes passion fruit (Passiflora edulis Sims, Passifloraceae) in the state of Espírito Santo (Culik et al., 2008), olive tree (Olea europaea L., Oleaceae) in Minas Gerais (Prado \& Silva, 2006) and in Rio Grande do Sul (Wolff et al., 2018). Although observed in only one $M$. nigra plant, at only one of the sampling sites evaluated in the municipality of Brasília, monitoring of this species is important due to its history and potential as a pest

\section{Conclusion}

Morus nigra is recorded for the first time as a host plant of $C$. brasiliensis, and $P$. pentagona is recorded for the first time in the Federal District, Brazil. More studies for a period of 12 months can be done and reveal aspects related to the population increase or reduction of these scale insetcs according to rainy and dry periods.

\section{Acknowledgements}

We thank to "Núcleo Interdisciplinar de Pesquisa (NIP), Centro Universitário ICESP” for financial support.

\section{References}

Claps, L. E., \& Wolff, V. R. (2003). Cochinillas Diaspididae (Hemiptera: Coccoidea) frecuentes en plantas de importancia económica de la Argentina y Brasil. Publicación Especial de la Sociedad Entomológica Argentina, 3, 1-58.

Claps, L. E., Wolff, V. R. S., \& González, R. H. (2001). Catálogo de las Diaspididae (Hemiptera: Coccoidea) exóticas de la Argentina, Brasil y Chile. Revista de la Sociedad Entomológica Argentina, 60, 9-34.

Culik, M. P., Martins, D. S., Ventura, J. A., \& Wolff, V. R. S. (2008). Diaspididae (Hemiptera: Coccoidea) of Espírito Santo, Brazil. Journal of Insect Science, 8, 1-6. https://doi.org/10.1673/031.008.1701

Ercisli, S., \& Orhan, E. (2007). Chemical composition of white (Morus alba), red (Morus rubra) and black (Morus nigra) mulberry fruits. Food Chemistry, 103, 1380-1384. https://doi.org/10.1016/j.foodchem. 2006.10.054

Ferris, G. F. (1937). Atlas of the scale insects of North America (pp. S1-S136). Stanford University Press Palo Alto, California.

Gallo, D., Nakano, O., Silveira-Neto, S., Carvalho, R. P. L, Batista, G. C., Berti Filho, E., ... Omoto, C. (2002). Entomologia Agrícola. Piracicaba: FEALQ, São Paulo.

García Morales, M., Denno, B., Miller, D. R., Miller, G. L., Ben-Dov, Y., \& Hardy, N. B. (2016). ScaleNet: a literature-based model of scale insect biology and systematic. Retrieve December 18, 2019, from http://scalenet.info

Gullan, P. J. (1984). A revision of the gall-forming coccoid genus Apiomorpha Rübsaamen (Homoptera: Eriococcidae: Apiomorphinae). Australian Journal of Zoology, 32, 1-203. https://doi.org/10.1071/AJZS097

Hempel, A. (1900). As coccidas brasileiras. Revista do Museu Paulista, 4, 365-537.

Hempel, A. (1912). Catalogos da fauna Brasileira editados pelo Museu Paulista São Paulo, Brasil. Diario Oficial São Paulo.

Kondo, T., Gullan, P. J., Peronti, A. L. B. G., Ramos-Portilla, A. A., Caballero, A., \& Villarreal-Pretelt, N. (2016a). First records of the iceryine scale insects Crypticerya brasiliensis (Hempel) and Crypticerya genistae (Hempel) (Hemiptera: Monophlebidae) for Colombia. Insecta Mundi, 0480, 1-9.

Kondo, T., Ramos-Portilla, A. A., Peronti, A. L. B. G., \& Gullan, P. J. (2016b). Known Distribution and Pest Status of Fluted Scale Insects (Hemiptera Momphlebidae Iceryini) in South America. Redia, XCIX, 187-195. https://doi.org/10.19263/REDIA-99.16.24

Lizer y Trelles, C. A. (1938). Cochinillas exóticas introducidas en la República Argentina y daños que causan. Jornadas Agronómicas y Veterinarias de la Facultad de Agronomía y Veterinaria de Buenos Aires, 341 - 362.

Miller, D. R., \& Davidson, J. A. (1990). A List of the Armored Scale Insect Pests. In D. Rosen (Ed.), Armored Scale Insects, Their Biology, Natural Enemies and Control. World Crop Pests. Elsevier, Amsterdam, Netherlands. 
Okamoto, F., Vidall, A. A., Funai, C. H., Martins, A., Furnaleto, F. P. B., \& Gazola, E. (2013). Diferentes comprimentos de estaca e substratos na produção de mudas de amoreira (Morus spp.). Revista Brasileira de Ciências Agrárias, 8, 218-222. https://doi.org/10.5039/agraria.v8i2a2415

Oliveira, T. F., Costa, C. C., Estevam, D. P., Medeiros, I. A., Lima, E. C., Santos, V. M., ... Oliveira, H. B. (2018). Morus nigra L.: revisão sistematizada das propriedades botânicas, fitoquímicas e farmacológicas. Archives of Health Investigation, 7, 450-454. https://doi.org/10.21270/archi.v7i10.3023

Padilha, M. M., Moreira, L. Q., Morais, F. F., Araújo, T. H., \& Alves-da-Silva, G. (2010). Estudo farmacobotânico das folhas de amoreira-preta, Morus nigra L., Moraceae. Revista Brasileira de Farmacognosia, 20, 621-626. https://doi.org/10.1590/S0102-695X2010000400024

Prado, E., \& Silva, R. A. (2006). Principais pragas da oliveira: biologia e manejo. Informe Agropecuário, 27, 79-83.

Silva d'Araujo, A. G, Gonçalves, C. R., Galvão, D. M., \& Goncalves, D. M. (1968). Fourth catalog of insects that live in Brazil. Parte II. Insects, hosts and natural enemies (Vol. 1, p. 622). Ministério da Cultura Rio de Janeiro, Brazil.

Silva Júnior, M. C., \& Lima, R. M. C. (2010). 100 árvores urbanas-Brasília: Guia de campo (p. 292). Brasilia: Ed. Rede de Sementes do Cerrado.

Watson, G. W. (2002). Arthropods of economic importance: Diaspididae of the world. An illustrated identification guide and information source. Expert Center for Taxonomic Identification (ETI), University of Amsterdam, The Netherlands.

Weiguo, Z., Yile, P., Zhifang, Z., Shihai, J., Xuexia, M., \& Yongping, H. (2005). Phylogeny of the genus Morus (Urticales: Moraceae) inferred from ITS and trnL-F sequences. African Journal of Biotechonology, 4, 563-569.

Wolff, V. R. S., Efrom, C. F. S., Aquino, D. A., \& Tonietto, A. (2018). Taxonomic study and population variation of scale insects (Hemiptera: Coccidae and Diaspididae) and associated parasitoids (Hymenoptera: Chalcidoidea) in an olive grove at Rio Grande do Sul, Brazil. Insecta Mundi, 0669, 1-8.

Wyckhuys, K. A. G., Kondo, T., Herrera, B. V., Miller, D. R., Naranjo, N., \& Hyman, G. (2013). Invasion of Exotic Arthopods in South America's Biodiversity hotspots and Agro-Production Systems. In J. Peña (Ed.), Potencial Invasive Pests of Agricultural Crops. CAB International. https://doi.org/10.1079/97818459 38291.0373

\section{Copyrights}

Copyright for this article is retained by the author(s), with first publication rights granted to the journal.

This is an open-access article distributed under the terms and conditions of the Creative Commons Attribution license (http://creativecommons.org/licenses/by/4.0/). 